was "Summer Sausage and Some Are Not" ; another was labelled "Sic Transit Gloria Tuesday."

His life, like his poetry and teaching, was sprinkled with humor. His children would earn "entertainment fees" by making him laugh. He could also use his wit to deftly disable intellectual opponents. Once when the two of us were testifying before a Senate subcommittee in Washington, a staff member sneered that Earl Warren and his brethren were injuring the judiciary's reputation. "Yes," Herman agreed, gently wagging his right index finger, "the Supreme Court is not what is used to be.", And, as the staff member began to bask in what he thought was victory, Herman quietly added: "And what's more it never was."

Herman's open-mindedness, his talents as scholar and teacher are important, but so were his moral character and his warmth as a human being. The trust his contentious colleagues at Chicago put in his moral integrity was one indicium, his election to the presidency of the APSA was another. I think the most important lesson Herman's whole life taught was that a person can be a superb scholar and, at the same time, a generous, caring human being.

Herman's love for Marguerite and his love and pride in his children and grandchildren were obvious, but he could invite others to share in his love. There was more than enough for each of us. At first we may have been his students or his colleagues, but soon we became his dear friends.

For that gift each of us can be forever grateful.

Walter F. Murphy

Princeton University

\section{James G. Smith}

It is with sorrow that West Chester University notes the death of James G. Smith, age 50, of natu- ral causes at his home in Philadelphia on June 28, 1995. Smith, an Associate Professor of Political Science had been a valued member of his department and the faculty since 1980 .

Smith, who had previously taught at Dickinson College, earned his Ph.D. at Indiana University (Bloomington) and held masters from the University of California and the University of Nevada.

Smith's research had focused on civil rights, presidential politics, African politics and the impact of music and literature on politics. In addition to serving on numerous committees, Dr. Smith was advisor to the Political Science Honorary Society, Pi Sigma Alpha, and to the Phi Beta Sigma fraternity. He was also an honorary member of the Friars Honors Society. In addition, he participated in community affairs.

\section{West Chester University}

\section{Owen Stratton}

Professor Owen (Pete) Stratton, who taught at Wellesley College from 1946 until his retirement in 1976, died of cancer at age 84 on June 7 at his home in Wellesley, MA. He held the Ralph Emerson Chair on the Wellesley faculty.

Professor Stratton pursued an early interest in environmental policy throughout his career, and also published articles on American politics, the presidency, and public administration. He served the federal government as a member of the Resources Program Staff of the Department of the Interior, as a consultant to the Federal Water Resources Council, and as a representative of the Secretary of the Interior on the Joint Interior-Agriculture North Cascades Study Team from 1963-1965.

Pete Stratton grew up in Idaho, graduated from Reed College in the depths of the Great Depression, served in the Civilian Conservation
Corps, and earned his M.A. and $\mathrm{Ph}$.D. degrees from Stanford University. He acquired first-hand experience in government with the Bureau of the Budget, the Office of Price Administration, and the Navy during the Second World War.

Pete was a consummate teacher at Wellesley, and had an enormous impact on the lives of many students. He also was a mentor to junior faculty, helping them to develop their teaching skills and cope with the transition from graduate student to professor.

Teaching and mentoring came naturally to Pete. He was a warm, genuine, open individual. He enjoyed people, and he never took himself or the study of politics too seriously. I fondly recall him walking across the campus, pipe in hand, laughing, with his attention focused on the student or students walking with him. He was a gifted raconteur, and invariably came up with a creative example to illustrate some analytical point about politics.

On a number of occasions I had the pleasure of team-teaching courses on American politics with Pete, and I enjoyed these experiences greatly. It is all too rare that junior faculty have the opportunity to observe a master at work, and to learn his or her skills first-hand.

Following his retirement from Wellesley, Pete returned to the study of American history, his first intellectual interest, and completed projects on the history of the American West, including the book Medicine Man, the memoirs of his father who was first a medicine show pitch man in the far West and later a self-taught country physician in Salmon, Idaho.

He is survived by his wife, Claire Zimmerman, Professor of Psychology at Wellesley; a niece, Jo Whitcomb of Salmon, Idaho; and a nephew, John Stratton of Flat Rock, North Carolina, as well as many close friends.

Alan Schechter
Wellesley College 